\title{
Evaluasi keberadaan ruang terbuka hijau di Kecamatan Tangerang, Kota Tangerang, Banten
}

\author{
Siti Ardila1*, Rully Besari Budiyanti ${ }^{1 *}$, Titien Suryanti ${ }^{*}$ \\ 1. Jurusan Arsitektur Lanskap, Fakultas Arsitektur Lanskap dan Teknologi Lingkungan, Universitas Trisakti, \\ Jl. Kyai Tapa, Jakarta, Indonesia \\ *E-mail: sitiardila011@gmail.com, rully@trisakti.ac.id, titiensr@yahoo.com
}

\begin{abstract}
Evaluation the existence of Green Open Space in Tangerang Sub-District, Tangerang City, Banten : Tangerang City is one of the cities in the Tangerang region which is known as a city of a thousand parks with various types and functions. Tangerang City is consists of 13 sub-districts, one of them is Tangerang SubDistrict that has an area of $17,45 \mathrm{~km}^{2}$ based on land use Tangerang Sub-District is has a more diverse and wider green open space and as an ecologically is complete for all aspect in landscape structure compared to other sub-districts. Landscape structure is an arrangement of landscape elements consisting of green open spaces in form of corridors as the green belt along the river, the green belt along the railroad, matrix as soccer field, network as the green belt along the way, and patches as road island (Godron, 1963: 83). Although as an ecologically is complete compared to other sub-districts, however, the Spatial Planning requires $30 \%$ and the area is green open space. For this reason, it is necessary to evaluate the existence of green open space, evaluation is done as an effort to achieve the goal of forming a system of green open space as an effort to increase the percentage of green open space to $30 \%$ of the total area. This research was conducted with a qualitative approach, while the qualitative stage is to evaluate the fulfillment of the criteria and each of the mapped green open spaces. Data collection is done by survey methods in the form of observations, questionnaires and interviews, whereas to do data analysis using the assessment method, which is often done to evaluate the existence of green open space (Besari, 2014).
\end{abstract}

Keywords: landscape structure, green open space system, assessment method

\section{Pendahuluan}

Berdasarkan tata guna lahan (land use) nya, Kecamatan Tangerang memiliki luas $14,53 \mathrm{~km}^{2}$, dari luas tersebut $15 \%$ merupakan ruang terbuka hijau (RTH) baik berupa koridor maupun yang berbentuk taman, sedangkan sisanya seluar $85 \%$ berupa kawasan perdagangan dan jasa (Dinas PUPR Kota Tangerang). RTH pada Kecamatan Tangerang secara land use memiliki keanekaragaman yang cukup, namun belum membentuk sebuah struktur lanskap yang merupakan susunan atau pola dari ruang atau komposisi dari elemen lanskap yang dibangun oleh bercak (patches), koridor (corridor), dominan (matrix) dan jaringan (network). RTH pada Kecamatan Tangerang secara struktur lanskap (ekologis) sudah memenuhi karena memiliki kelengkapan baik berupa bercak (patches), koridor (corridor), dominan (matrix) dan jaringan (network).

Keberadaan RTH di Kecamatan Tangerang baik secara ekologis maupun land use belum membentuk sebuah sistem RTH, sehingga satu RTH dengan RTH lainnya masih berdiri sendiri, untuk itu perlu dilakukan evaluasi terhadap keberadaan RTH tersebut, sehingga dapat menaikan presentasi luas RTH menjadi 30\% bagi Kecamatan Tangerang, Kota Tangerang, Banten.

\section{Metode}

\subsection{Lokasi Penelitian}

Lokasi penelitan terletak di Kecamatan Tangerang, luas Kecamatan Tangerang $14,53 \mathrm{~km}^{2}$. Secara geografis Kecamatan Tangerang terletak di titik 0 kilometer dan berada pada $6^{\circ} 10^{\prime} 19,81^{\prime \prime}$ LS dan $106^{\circ} 37^{\prime} 59,29^{\prime \prime}$ BT. Secara administrasi, Kecamatan Tangerang terdiri dari 8 kelurahan dengan batas wilayah sebagai berikut, gambar 1 : 
a. Sebelah Utara, Kecamatan Batuceper dan Kecamatan Neglasari,

b. Sebelah Timur, Kecamatan Cipondoh dan Kecamatan Cibodas,

c. Sebelah Selatan, Kecamatan Pinang dan Kecamatan Cikokol,

d. Sebelah Barat, Kecamatan Karawaci.

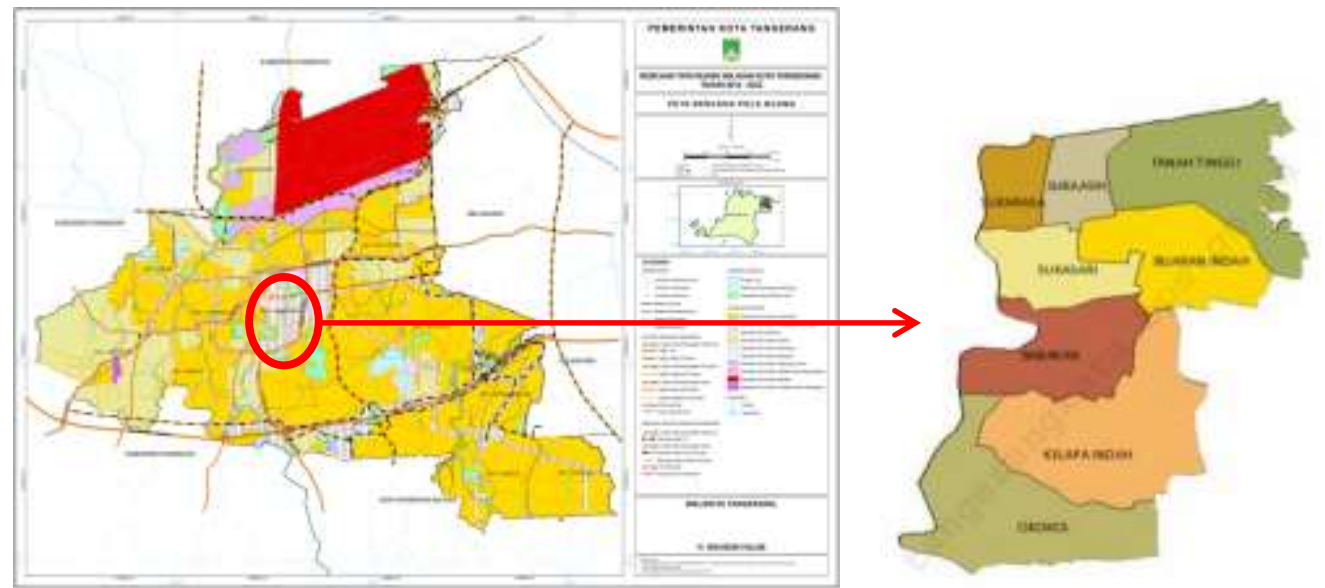

Gambar 1. Peta Lokasi Penelitian Kecamatan Tangerang, Kota Tangerang Banten.

(Dinas Pemerintahan Kota Tangerang)

\subsection{Alat dan Bahan}

Alat dan bahan yang digunakan dalam melakukan penelitian ini seperti alat tulis, alat gambar, kamera, laptop dan program aplikasi komputer (Microsoft Word, AutoCAD dan ARC View 3.10), peta dasar Kecamatan Tangerang, Website Pemerintah yaitu : www.kec-tangerang.tangerangkota.go.id serta catatan lainnya.

\subsection{Metode Penelitian}

Penelitian ini dilakukan di Kecamatan Tangerang dengan meng-evaluasi seluruh ruang terbuka hijau yang ada di Kecamatan Tangerang, penelitian bersifat kualitatif-kuantitatif, dimana pada tahap kualitatif digunakan untuk memetakan RTH secara ekologis, sedangkan tahap kuantitatif untuk meng-evaluasi pemenuhan kriteria dari masing-masing RTH yang sudah di petakan. Dilakukan pada bulan November 2019 - Januari 2020, dengan metode pengumpulan data menggunakan metode survey berupa pengamatan, kuesionerdan wawancara. Dan metode analisis data menggunakan metode asesmen yang sering dilakukan untuk melakukan evaluasi keberadaan RTH (Besari, 2014).

\section{Hasil dan Pembahasan}

\subsection{Studi Pustaka}

\subsubsection{Struktur Lanskap}

Struktur lanskap menurut Dramstad at all (1996:10), adalah susunan atau pola dari ruang atau komposisi dari berbagai elemen lanskap berupa : bercak (patches), koridor (corridor), dominan (matrix) dan jaringan (network).

1. Bercak (patches), merupakan gangguan heterogenitas yang ada dimanapun. Dapat berupa pulau, baik pulau jalan maupun area pertanian, hutan kota, single tree dan perbukitan. Dapat diukur atau dianalisis berdasarkan luas, lokasi dan jumlah.

2. Koridor (corridor), pembatas dari sebuah lanskap, biasanya digunakan sebagai sebuah sistem transportasi untuk suatu pergerakan yang terjadi disekitar area yang dibatasi oleh lanskap lainnya. Dapat berupa jalur hijau jalan, kereta api dan kanal. Dapat di diukur atau dianalisi berdasarkan luas, lokasi dan pola (lurus/berkelok-kelok).

3. Dominan (matrix), kategori elemen lanskap utama, memiliki area yang relatif lebih besar dibandingkan dengan struktur lanskap lainnya. Dapat berupa kawasan perhutanan, permukiman dan hijau (lapangan, dsb). Dapat diukur atau dianalisis berdasarkan luas dan lokasi. 
4. Jaringan (network), penghubung yang dapat mengkoneksi sebuah lanskap. Dapat berupa jalur hijau jalan maupun jalur hijau lainnya. Dapat diukur atau dianalisis berdasarkan luas, lokasi dan pola (lurus/berkelok-kelok).

\subsubsection{Klasifikasi Ruang Terbuka Hijau}

Menurut Chiara dan Koppelman (1975:42-44), klasifikasi ruang terbuka hijau terdiri dari :

1. Kawasan perhutanan, area yang dibiarkan/berada dalam kondisi alami maksimum untuk nilai visual aesthetic (keindahan), geologi dan ekologi.

2. Kawasan lindung alami, akses terbatas dan pengembangannya terkendali, diperlukan untuk perlindungan area khusus sebagai nilai pemandangan dan alam lainnya.

3. Taman kota, taman yang lebih dekat dengan pengembangan kota metropolitan.

4. Rekreasi, ruang terbuka yang dikembangkan dan diperuntukkan untuk fasilitas rekreasi di luar ruangan.

5. Ruang terbuka kota, ruang terbuka yang membentuk, mengontrol dan menentukan lokasi pengembangan kota.

\subsubsection{Konsep Perencanaan Lanskap}

1. Konsep Pola Jaringan Sistem Ruang Terbuka Hijau,

Menurut Heckscher (1977: 197), Olmsted membuat konsep Greenbelt dimana konsep ini dijadikan sebagai sebuah landasan dasar untuk membuat sistem ruang terbuka hijau, tujuannya untuk menghubungkan ruang terbuka hijau yang bentuknya taman kota, taman lingkungan dan jalur hijau lainnya, yang nantinya akan di arahkan kearah Sungai Muddy, karena menurut Olmsted sungai tidak bisa dijadikan sebagai suatu sistem, karena sungai merupakan sebuah sistem yang berdiri sendiri.

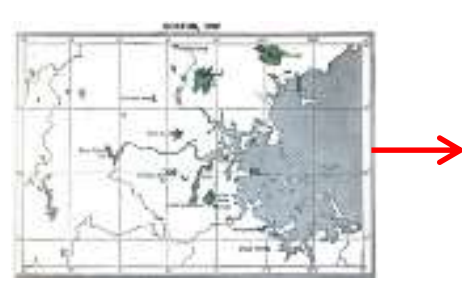

a. Sebelum

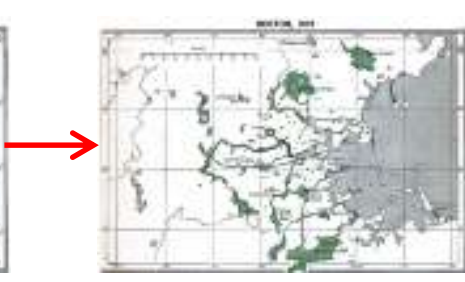

b. Sesudah

Gambar 2. Boston Park System (Heckscher, 1977:197)
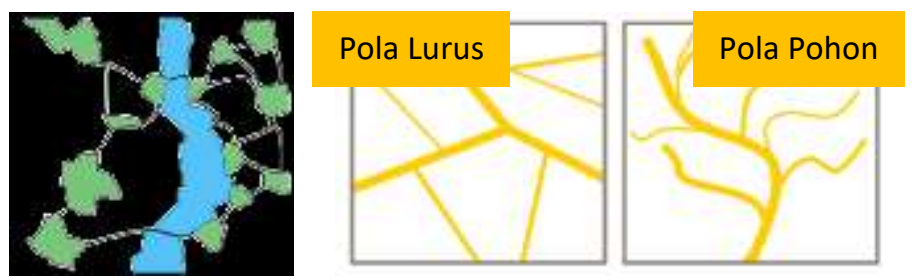

Gambar 3. Contoh dari Struktur Lanskap Jaringan (network) berupa Pola Jaringan (Landscape Ecology, 2014, http://ecologics.ucalgary.ca/lab/science/landscape-ecology/)

2. Konsep Pola Linier Sistem Ruang Terbuka Hijau,

Menurut Heckscher (1977:202), sistem Kansas City, Missouri, yang dibuat oleh George Kessler. Memadukan struktur alami kota dengan struktur artifisial kota sehingga kota tersebut menjadi lebih baik dan lebih indah. Dalam sistem pola linier ini ruang terbuka hijau yang semula parsial menjadi sebuah sistem ruang terbuka hijau dengan adanya penambahan ruang terbuka hijau lain. Bentuk ruang terbuka hijau penambahan ini dapat berupa jalur hijau jalan, taman-taman kecil dan lahan hijau seperti contoh yang ada pada gambar 4 . 


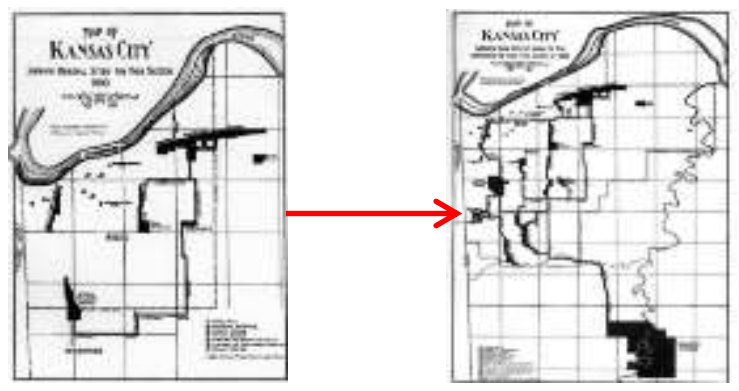

a. Sebelum

b. Sesudah

Gambar 4. Konsep Pola Sistem Linier (Heckscher, 1977:200-201)

3. Konsep Pola Alami Sistem Ruang Terbuka Hijau,

Menurut Heckscher (1977:206), sistem di Minneapolis yang dibuat oleh Cleveland, hanya mempertahankan karakteristik dan potensi ruang terbuka hijau sebuah kota, sehingga dalam membuat sebuah sistem ruang terbuka hijau Cleveland hanya memanfaatkan ruang terbuka hijau eksisting. Cleveland hanya memanfaatkan fungsi dan visual dengan memanfaatkan kanopi pohon yang memiliki diameter lebih dari 5 meter dan juga membuat pola jaringan untuk menghubungkan ruang terbuka hijau satu dengan yang lainnya seperti contoh yang ada pada gambar 5 .

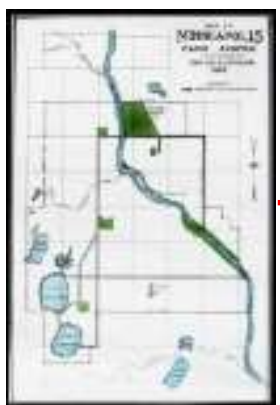

a. Sebelum

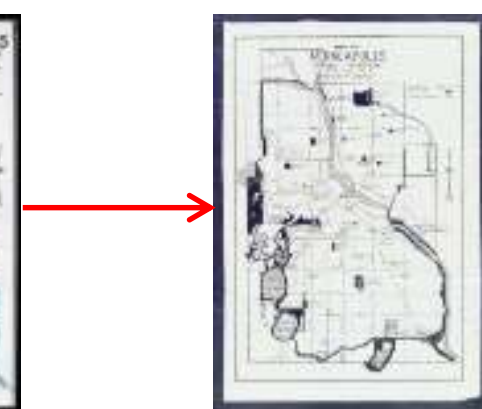

b. Sesudah

Gambar 5. Konsep Pola Sistem Alami (Heckscher, 1977:207)

\subsection{Analisa Ruang Terbuka Hijau berdasarkan Ekologis (Struktur Lanskap)}

Berdasarkan Struktur Lanskap, Kecamatan Tangerang memiliki banyak sekali keragaman dalam segi klasifikasinya seperti terlihat pada gambar 6 .

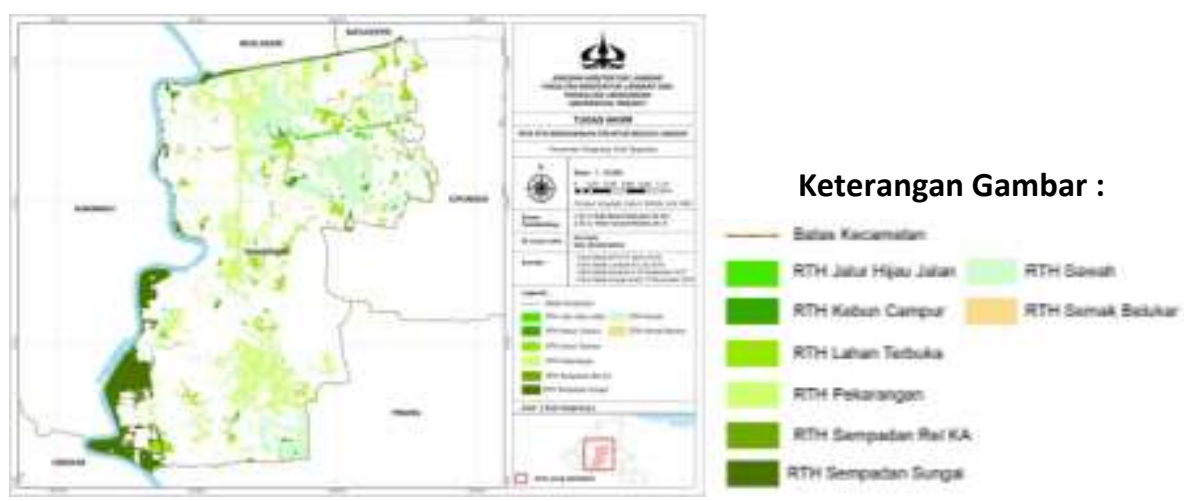

Gambar 6. Peta Ruang Terbuka Hijau berdasarkan Ekologis (Dinas PUPR Kota Tangerang)

Dalam melakukan analisa RTH berdasarkan ekologis, digunakan indikator berupa luas, lokasi, pola dan jumlah. Hasil analisis menunjukan sebagai berikut : 
4. Bercak (patches), berupa semak belukar banyak terdapat di Kelurahan Tanah Tinggi dengan luas antara 2 ha sampai 3 ha, sehingga sistem RTH yang sesuai adalah dengan pola alami.

5. Koridor (corridor), berupa sempadan sungai banyak terdapat di Kelurahan Cikokol dengan luas antara 30 ha sampai 41 ha dengan pola linier, sehingga sistem RTH yang sesuai adalah dengan pola alami.

6. Dominan (matrix), berupa lahan terbuka banyak terdapat di Kelurahan Tanah Tinggi dengan luas antara 6 ha -8 ha, sehingga sistem RTH yang sesuai adalah dengan pola jaringan.

7. Jaringan (network), berupa sempadan rel kereta api banyak terdapat di Kelurahan Sukasari dengan luas antara 20 ha sampai dengan 31 ha dengan pola linier, sehingga sistem RTH yang sesuai adalah dengan pola alami.

\subsection{Analisa Ruang Terbuka Hijau berdasarkan Tata Guna Lahan (Land Use)}

Berdasarkan land use nya, Kecamatan Tangerang memiliki banyak sekali keragaman dalam segi klasifikasi ruang terbuka hijau, seperti terlihat pada gambar 7.

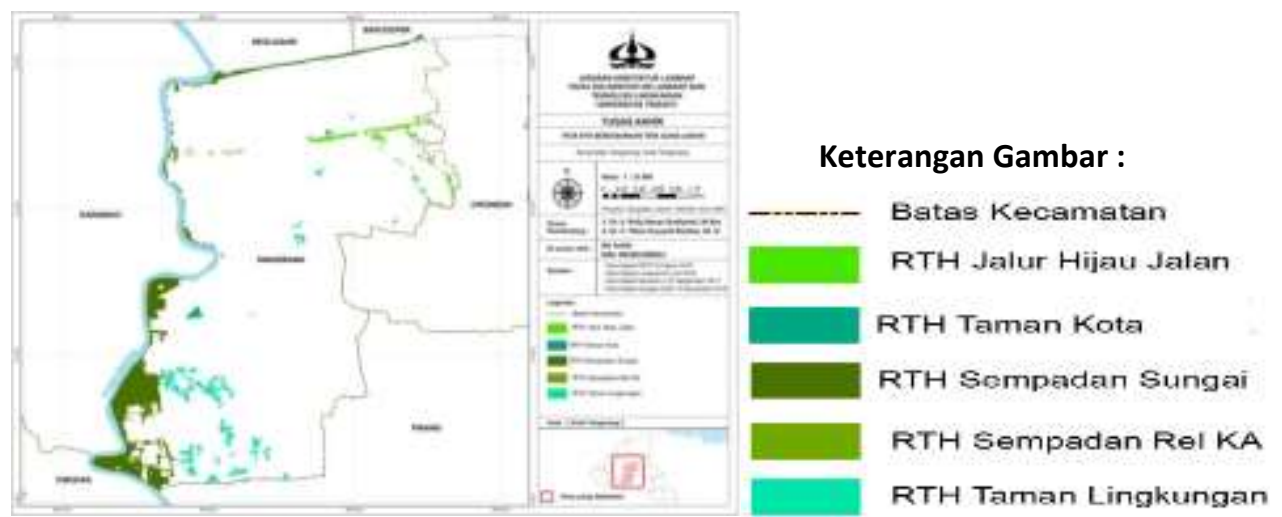

Gambar 7. Peta Ruang Terbuka Hijau berdasarkan land use (Dinas PUPR Kota Tangerang)

Untuk melakukan analisa RTH berdasarkan land use yang ada di Kecamatan Tangerang digunakan indikator berupa luas dan lokasi. Adapaun klasifikasi RTH yang ada di Kecamatan Tangerang, meliputi :

1. Bentuk RTH berupa Bantaran Sungai, banyak terdapat di Kelurahan Cikokol dengan luas antara 30 ha sampai dengan 41 ha dengan pola linier, sehingga sistem RTH yang sesuai adalah dengan pola alami.

2. Bentuk RTH Jalur Hijau Kereta Api, banyak terdapat di Kelurahan Sukasari dengan luas antara 20 ha sampai dengan 31 ha dengan pola linier, sehingga sistem RTH yang sesuai adalah dengan pola alami.

3. Bentuk berupa Jalur Hijau Jalan, banyak terdapat di Kelurahan Tanah Tinggi dengan luas antara 18 ha dengan pola linier, sehingga sistem RTH yang sesuai adalah dengan pola jaringan.

4. Bentuk Taman Kota, banyak terdapat di Kelurahan Cikokol dengan luas 7 ha, sehingga sistem RTH yang sesuai adalah dengan pola jaringan.

5. Bentuk Taman Lingkungan, banyak terdapat di Kelurahan Cikokol dengan luas antara 2 ha sampai dengan 3 ha, sehingga sistem RTH yang sesuai adalah dengan pola jaringan.

\subsection{Hasil Evaluasi Peta Overlay Ruang Terbuka Hijau berdasarkan Ekologis dan Land Use}

Kecamatan Tangerang yang terdiri dari 8 kelurahan memiliki keragaman ruang terbuka hijau (RTH) dari hasil evaluasi dengan teknik overlay gambar 8 dan Tabel 1 antara peta ekologi (struktur lanskap) dan klasifikasi tata guna lahan (land use), ditemukan bahwa keragaman tersebut dapat dikembangkan menjadi sebuah sistem ruang terbuka hijau.

Konsep usulan perencanaan lanskap untuk sistem ruang terbuka hijau di Kecamatan Tangerang diusulkan dengan menggunakan berbagai pola, antara lain ; pola jaringan, linier dan alami. Diharapkan dapat menjadi model bagi kecamatan-kecamatan lainnya di Kota Tangerang untuk waktu 5 tahun mendatang (jangka pendek). 


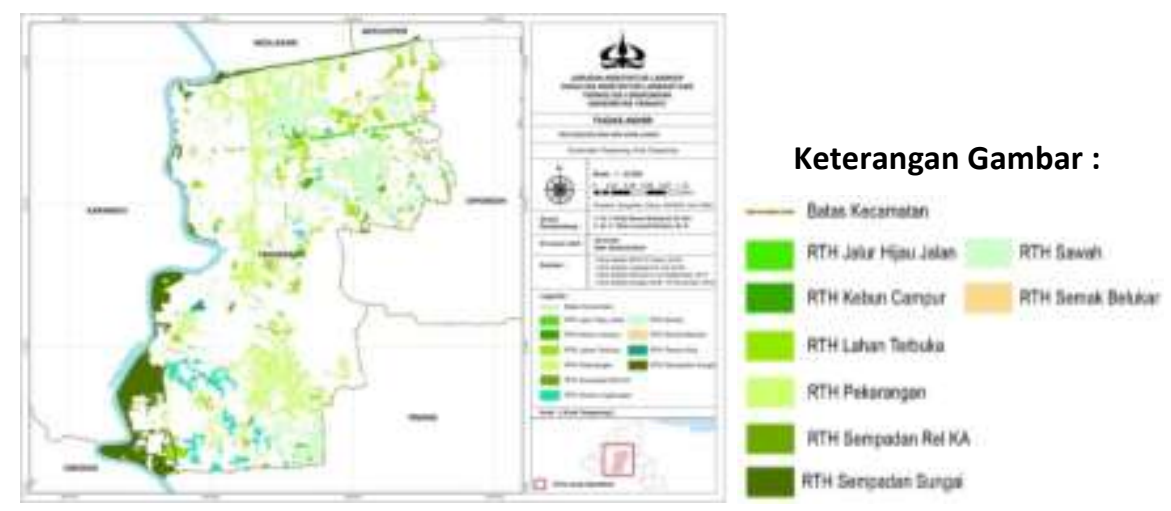

Gambar 8. Peta Ruang Terbuka Hijau berdasarkan Ekologis dan Tata Guna Lahan (Dinas PUPR Kota Tangerang)

Tabel 1. Hasil Evaluasi Peta overlay ruang terbuka hijau berdasarkan ekologis dan land use

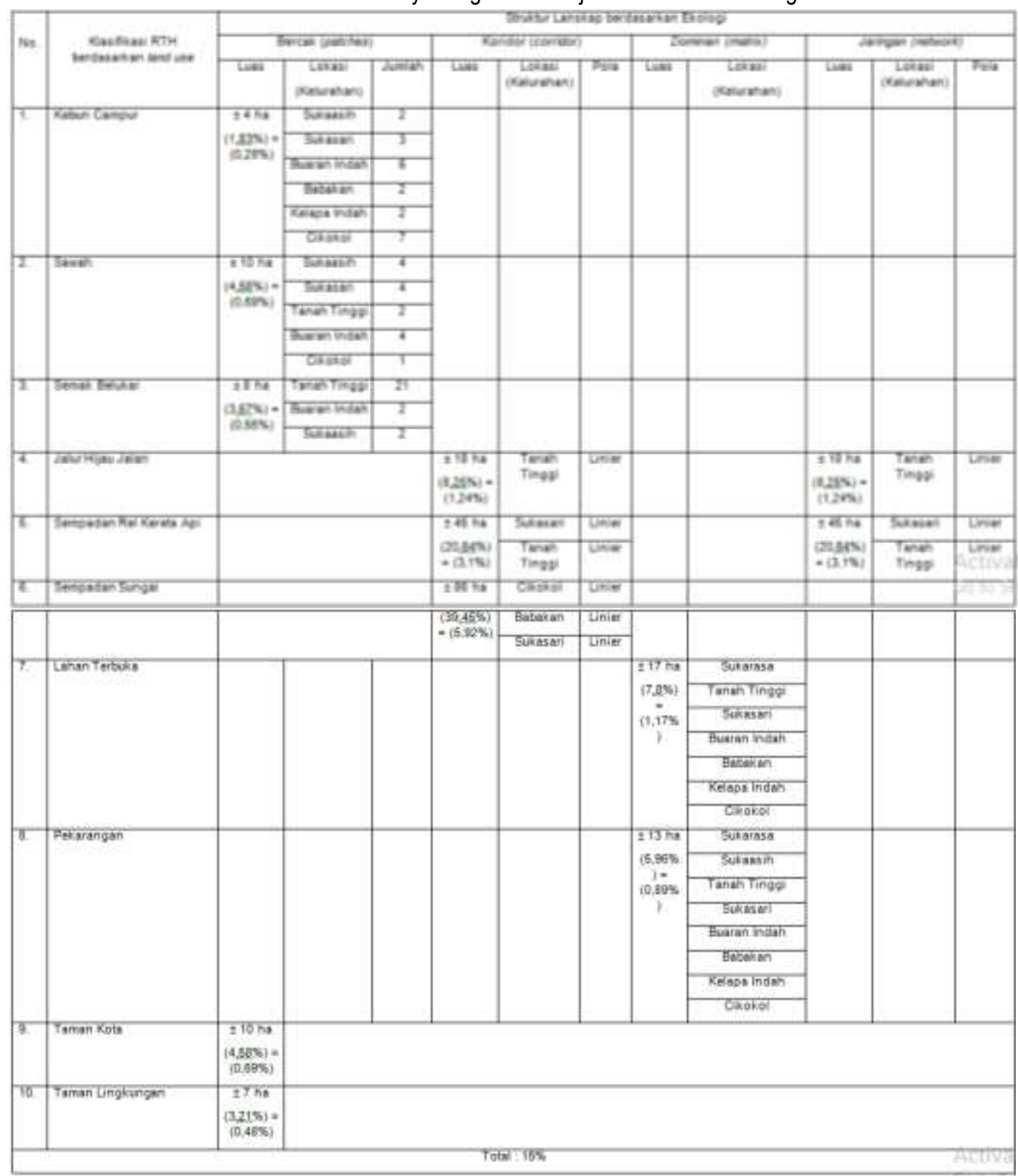




\subsection{Hasil Penelitian}

Dari gambar 9 terlihat bahwa RTH yang ada di setiap kecamatan di Kota Tangerang masih belum terhubung satu sama lain. Demikian pula RTH di Kecamatan Tangerang yang belum terintegrasi terhadap kecamatan lainnya, sehingga secara keseluruhan RTH pada Kota Tangerang belum terhubung satu sama lain. Kondisi tersebut menggambarkan bahwa adanya peluang untuk meningkatkan presentasi RTH dari 15\% menjadi $30 \%$, yaitu dengan menghubungkan antar RTH kecamatan, sehingga dapat membentuk sebuah sistem RTH kota. Usulan ini diperkirakan dalam jangka waktu 5 tahun akan tercapai (jangka pendek).

Konsep sistem RTH antar kecamatan di Kota Tangerang diusulkan dengan menggunakan pola linier, yaitu perpaduan RTH alami kota, baik berupa koridor sempadan sungai dan kereta api dengan RTH nonalami sebagai upaya untuk meningkatkan presentase RTH dari $15 \%$ menjadi $30 \%$. Bentuk sistem RTH ini dapat berupa sempadan sungai, jalur hijau jalan, jalur hijau kereta api dan taman-taman kecil yang dapat dimanfaatkan untuk rekreasi. Pada gambar 10 disampaikan ilustrasi sistem RTH antar kecamatan dengan pola linier.
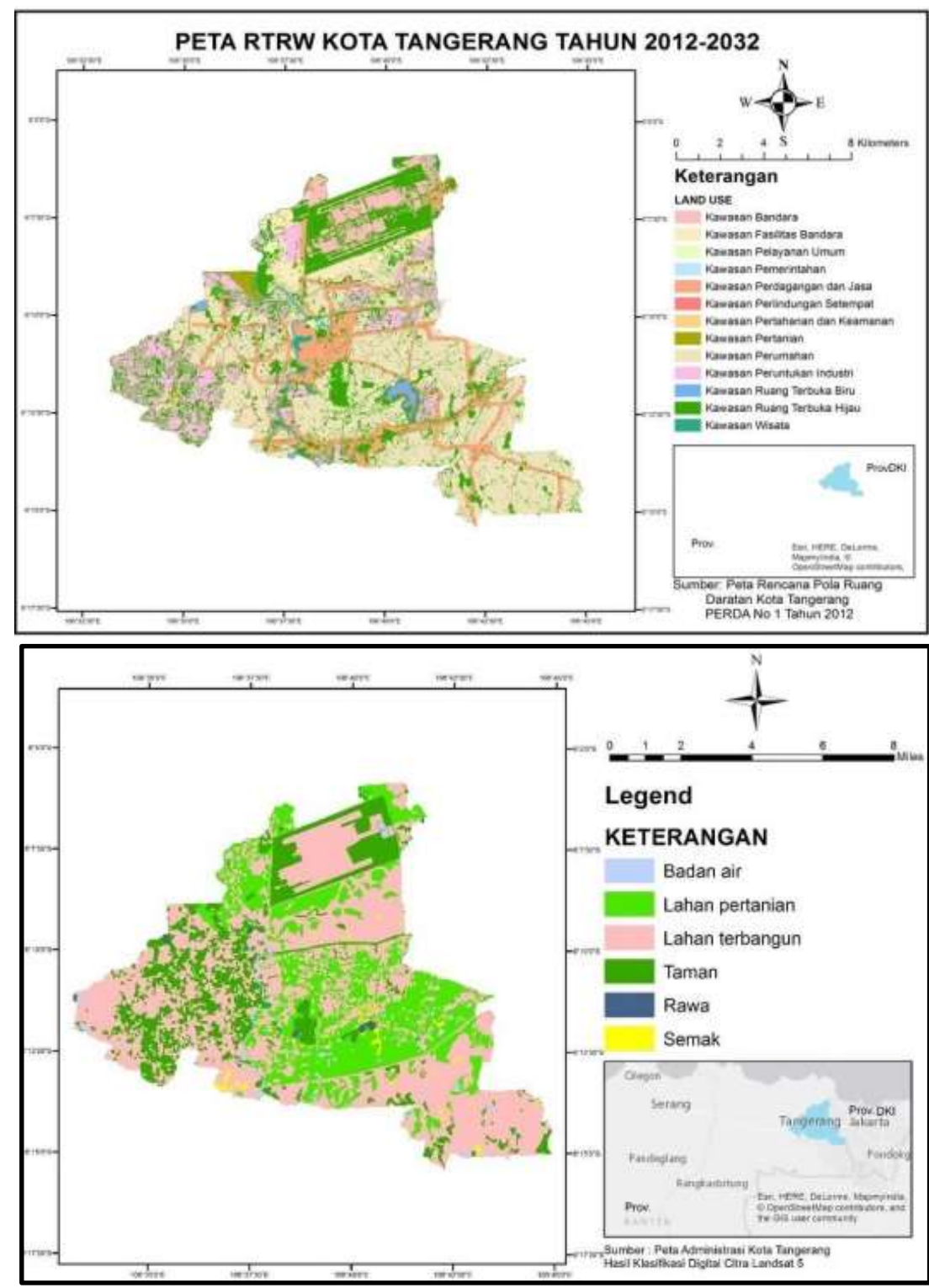

Gambar 9. Peta Tata Guna Lahan (land use) Kota Tangerang

(Peta RTRW Kota Tangerang 2012 - 2023) 


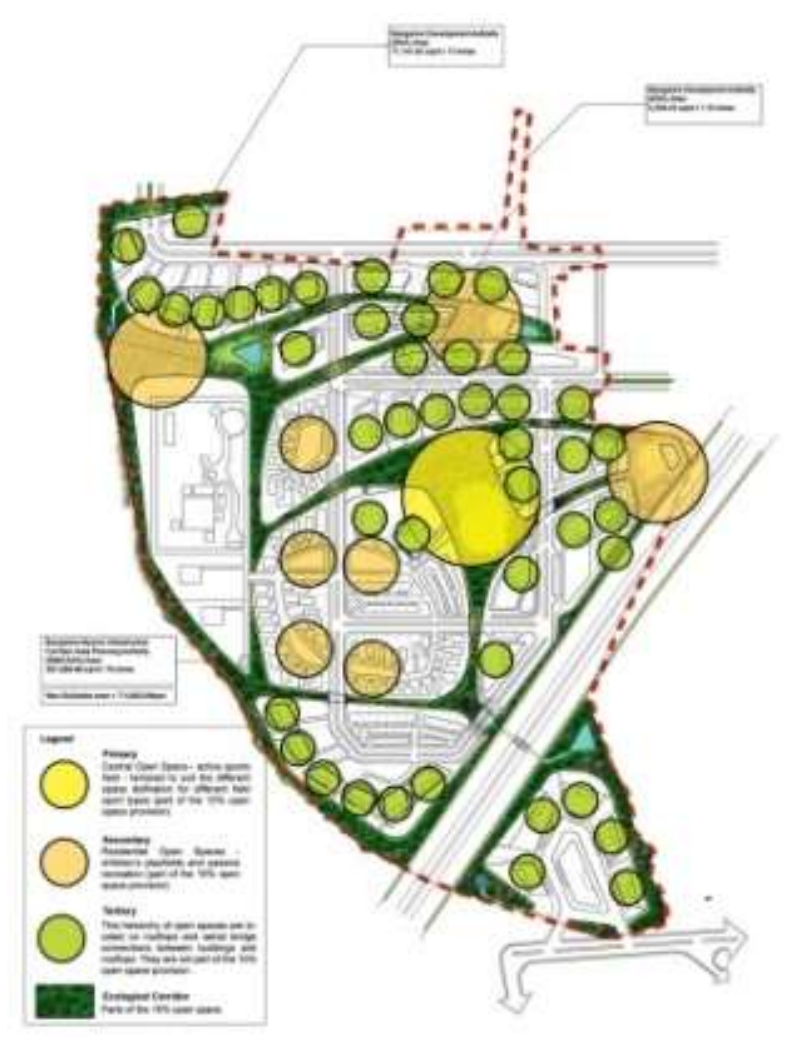

Gambar 10. Ilustrasi sistem ruang terbuka hijau menggunakan konsep pola linier

(ARCHNET. 2011. https://archnet.org/sites/6899/media_contents/77211)

\section{Simpulan}

Dari perhitungan ruang terbuka hijau eksisting yang ada di Kecamatan Tangerang, setelah dibuat peta overlay berupa ruang terbuka hijau berdasarkan ekologi dan land use yang masing-masing kelurahan di analisis satu sama lain berdasarkan ruang terbuka hijau ekologis dan land use maka sebuah sistem perkotaan ini dapat teralisasikan, dan mendapatkan konsep sistem, yaitu perpaduan antara konsep sistem pola linier dan konsep sistem pola jaringan. Sama halnya dengan sistem ruang terbuka hijau yang ada di Boston yaitu Boston's Emerald Necklace City Parks.

\section{Daftar Pustaka}

August, Heckscher. 1977. Open Spaces: The Life of American Cities. New York: Harper \& Row

Chiara, Joseph de dan Lee Koppelman. 1982. Urban Planning and Design Criteria. London: Van Nostrand Reinhold.

Dramstad, Wenche E. et. all. 1996. Landscape Ecology Principles in Landscape Architecture and Land-Use Planning. USA : Island Press.

Forman, Richard and Michael Gordon. 1983. Landscape Ecology. John Wiley \& Son : New York.

Landscape I Ecology I Informatics. Landscape Ecology. (Accessed on 18 January 2019). Available online at: http://ecologics.ucalgary.ca/lab/science/landscape-ecology/

Pemerintah Kota Tangerang. 2010. Rencana Tata Ruang Kota Tangerang 2010-2030. Tangerang RTRW Kota tangerang 2010-2030.

Rully, Besari B. 2016. Metoda Penilaian Wilayah Pesisir: Upaya Mengetahui Karakteristik Lanskap Sensitif. Temu IImiah IPBLI 2016 [internet]. [diakses 23 November 2019]. Tersedia dari https://temuilmiah.iplbi.or.id/wp-content/uploads/2016/12/IPLBI2016-A-059-062-Metoda-PenilaianWilayah-Pesisir-Upaya-Mengetahui-Karakteristik-Lanskap-Sensitif.pdf

Yang, Zhifeng (Ed.). 2013. Eco-Cities A Planning Guide.United States of America: Taylor \& Francis Gorup, LLC. 